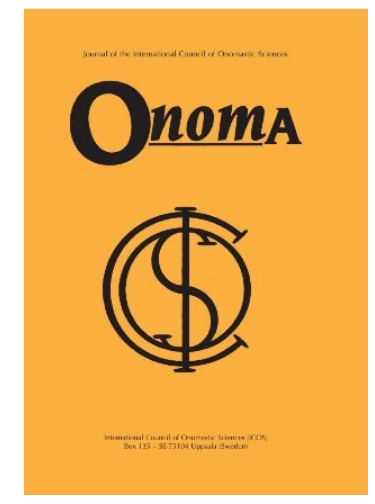

Onoma 54

Journal of the International Council of Onomastic

Sciences

ISSN: 0078-463X; e-ISSN: 1783-1644

Journal homepage: https://onomajournal.org/

\title{
The realisation of traditional local dialectal features in the address names of two Western Norwegian municipalities
}

DOI: $10.34158 /$ ONOMA.54/2019/4

\section{Wen Ge}

University of Iceland

Sæmundargata 14

102 Reykjavík Iceland

ge.wen25@icloud.com

To cite this article: Wen Ge. 2019. The realisation of traditional local dialectal features in the address names of two Western Norwegian municipalities. Onoma 54, 53-75. DOI: 10.34158/ONOMA.54/2019/4

To link to this article: https://doi.org/10.34158/ONOMA.54/2019/4

(C) Onoma and the author.

The realisation of traditional local dialectal features in the address names of two Western Norwegian municipalities

Abstract: Norway is often seen as a dialect paradise: it is acceptable to use dialects in both private and public contexts. Does this high degree of dialect diversity and tolerance also apply to Norwegian place-names? In order to shed light on this question, I will examine address names in two former municipalities in Hardanger, a traditional Western Norwegian district, as for the degree of the visibility of a selection of the traditional local dialectal features. Features retained in the names will be evaluated in terms of to what extent they are permitted by the current place-name regulations, so as to see whether dialect diversity and tolerance apply to Norwegian place-names.

Keywords: Place-name standardisation, rural area, traditional dialect, Norway. 
La réalisation de caractéristiques dialectales traditionnelles et locales dans les noms d'adresses dans deux communautés dans l'ouest de la Norvège

Résumé : La Norvège est souvent perçue comme un paradis des dialectes : leur emploi est universellement accepté dans les contextes même privés comme publiques. Cette haute mesure de diversité dialectale et de tolérance, s'appliquent-elles également aux noms de lieux norvégiens ? Afin d'illuminer cette question, j'examinerai des noms d'adresses de deux municipalités précédentes dans la région de Hardanger, une région traditionnelle dans l'ouest du pays, pour constater la mesure de visibilité d'une sélection des caractéristiques dialectales traditionnelles locales. Des caractéristiques conservées dans les noms locaux seront évaluées à la lumière de leur compatibilité avec les régulations actuelles à propos de noms de lieux, afin de voir si la diversité dialectale s'applique aux noms de lieux.

Mots-clés : Standardisation de noms de lieux, région rurale, dialecte traditionnel, Norvège.

Die Realisierung der traditionellen lokalen Dialektmerkmale in den Adressenamen zwei westnorwegischer Gemeinden

Zusammenfassung: Norwegen wird oft als Dialektparadies betrachtet: Dialekte werden sowohl in privaten als auch in öffentlichen Kontexten akzeptiert. Gilt die hohe Dialektvielfalt und -toleranz auch für norwegische Ortsnamen? Um diese Frage zu erhellen, untersuche ich Adressenamen in zwei ehemaligen Gemeinden in Hardanger, einem historischen westnorwegischen Region, in Hinsicht auf den Grad der Sichtbarkeit traditioneller lokalen Dialektmerkmalen. Es wird geprüft, inwiefern die Merkmalen in den Namen durch aktuelle Regelungen der Ortsnamennormierung erlaubt werden. Somit lässt sich erkennen, ob die Dialektvielfalt und -toleranz für norwegische Ortsnamen gilt.

Schlüsselbegriffe: Ortsnamennormierung, rurale Region, traditioneller Dialekt, Norwegen. 


\title{
The realisation of traditional local dialectal features in the address names of two Western Norwegian municipalities
}

\author{
WEN GE (戈文)
}

\section{Introduction}

Norway is considered a dialect paradise: it is appropriate to use dialects not only in private contexts, such as with family and friends, but also in public domains, such as at university and in parliament (Røyneland 2009: 7). Compared to most other European countries, Norway has preserved its dialects much better and therefore enjoyed a high degree of dialect diversity (ibid.: 8, 14).

Does this high degree of dialect diversity and tolerance also apply to Norwegian place-names? ${ }^{1}$ To shed light on this question, I will examine address names in terms of the visibility of traditional local dialectal features in two former municipalities in Hardanger, a traditional district in Western Norway: Granvin and Ullensvang. ${ }^{2}$ Address names refer to "names of streets, roads, paths, squares or areas used as part of the official address" (Schedule of the Land Register 2009, Forskrift om eiendomsregistrering in the References). Reasons for examining address names in those two municipalities are 1) there has been some good research on the place-names and dialect of Hardanger and 2) information on place-names in Granvin and Ullensvang is, unlike most of the other municipalities in Hardanger, available in Hordanamn, a place-name database central to this study. Local dialectal features are defined as features that belong to the traditional dialect and are not permitted in standard written language but might be approved by place-name regulations. ${ }^{3}$ I aim to answer two questions:

1) To what extent are the local dialectal features visible in the address names in the two municipalities?

2) To what extent does the realisation of the local dialectal features deviate from the place-name regulations?

1 This refers to linguistically Norwegian place-names. In Norway, there are also placenames with origins in Sámi and Kven languages, but they are not dealt with in this article.

2 Granvin and Ullensvang have now been merged into one municipality after an administrative reform which came into force on 1 January 2020, after this study was completed.

3 Henceforth, I will refer to "local dialectal features", not indicating "traditional" every single time. 


\section{Literature review}

\subsection{General language situation in Norway: Two written standards and dialects}

It is necessary to introduce the general language situation in Norway first, as it is related to the place-name situation.

There are two written, mutually intelligible standards of the Norwegian language: Bokmål and Nynorsk. To understand this unique situation, one has to look into the history of Norway. After its independence from Denmark in 1814 , Norway underwent a long struggle to gain its own written standards. In 1885, Riksmål and Landsmål, which Bokmål and Nynorsk used to be called until 1929, were recognised as two co-official written forms (Landsmål 2018). Bokmål is a result of a gradual Norwegianisation of the Danish written standard with "the Dano-Norwegian dialect of the upper middle classes in the capital Christiania (later Oslo)" as model (Røyneland 2009: 11-12). By contrast, Nynorsk, with Danish as its anti-model, is based on a common denominator of Norwegian rural dialects. Despite the official equal status, Nynorsk has been dominated by Bokmål from the beginning. Today, Nynorsk is used by about $10-12 \%$ of the Norwegian population and primarily on the west coast and in rural areas (ibid.: 12).

The relatively high degree of dialect diversity in Norway should also be understood historically. Nynorsk, which is based on Norwegian dialects, has made a significant contribution to the high status of the Norwegian dialects (Røyneland 2009: 7-8). Additionally, as decided by the Norwegian Parliament in 1878 , teachers should follow the local dialect spoken by pupils in teaching in elementary and secondary schools, instead of any hypothetical spoken standard. This principle is still followed today and is part of the Norwegian Education Act. This explains "the continued use of local dialects in Norway" and "the preparedness and willingness to understand people's dialects in polylectal communication" (ibid.: 11). The strong position of the dialects was further enhanced by radical political movements in the 1970s fighting for use of dialects and Nynorsk (ibid.: 14).

Both Bokmål and Nynorsk are currently co-official guidelines for placename standardisation, but local dialectal forms are only allowed for special reasons. This will be elaborated upon below.

\subsection{Place-name standardisation in Norway}

\subsubsection{Regulation: General}

Place-name standardisation varies between different countries in terms of the approaches to standardisation and related organisation, principles, policies and procedures (UNGEGN 2006: 2). In Norway, the standardisation of place-names concerns only the spelling of place-names. There are several regulations on the spelling of place-names in Norway today. The Place-Name Act (Lov om stadnamn 
in the References), which was passed in 1990 (with later amendments), is the fundamental guideline for the standardisation of place-names. The aim of the act is "to take care of place-names as linguistic cultural heritage, provide them with a written form, which is practical and does not obscure the meaning of the name, and contribute to knowledge of and active use of the names" (Place-Name Act 1990). The most crucial rules in the act can be summarised into two categories: 1) the spelling of place-names and 2) the organisation of consultancy apparatus and the procedure for determining spellings as well as appeal mechanism.

Additionally, the Schedule of the Place-Name Act (Forskrift om stadnamn in the References) prepared by the Ministry of Culture provides further details on place-name standardisation. There are also the Supplementary Rules for the Spelling of Norwegian Place-Names set by the Language Council of Norway and acknowledged by the Ministry of Culture (Språkrådet 2018).

Many public bodies often ignore the place-name consultancy services, particularly municipalities (Helleland 2002: 70). Many decisions concerning the spelling of place-names made on the local level breach the act, which can be explained by "the lack of knowledge of the act, the lack of resources to follow up the act and some degree of reluctance against the standardisation rules" (loc. cit.).

\subsubsection{Regulation: The spelling of address names with a focus on local dialectal features}

According to $\S 1$ and $\S 5$ of the Place-Name Act (1990), municipalities have the power to determine the spelling of address names in the municipalities and must follow the act. $\S 4$ stipulates how the spelling of place-names ought to be:

If nothing else is laid down in this act, the adoption of spelling of place-names ought to take a starting point in the inherited local pronunciation. ${ }^{4}$ The spelling should follow the current standard orthographical principles for Norwegian and Sámi $[\ldots]^{5}$

Furthermore, $\S 1$ first subsection in the Schedule of the Place-Name Act (2017) indicates general rules on Norwegian place-names:

Place-names that contain generally recognisable words or name elements should be written in accordance with the current standard orthography, if nothing else is stated in the rules below. ${ }^{6}$ Place-names that contain extinct or unclear elements

4 According to $\S 2$ in the act, this means "pronunciation which is passed down from earlier generations, and has been usual locally, and is still in living use."

The quotes have been translated from Norwegian and emphasized by the author.

5 The orthographical principles refer to "a set rules or conventions for how individual sounds or combination of individual sounds should be written, and how unstandardised words should be written in accordance with (to-Norwegian-adapted) pronunciation" (Språkrådet 2018).

6 Standard orthography refers to "the orthographies for Bokmål and Nynorsk that are officially in force", i.e. in accordance with spelling rules (Språkrådet 2018). A standard orthographical form is thus a dictionary form. 
should be written in accordance with the spelling rules. Should the spelling have been used for a long time and is well-known and well-established, standard orthography and orthographic principles can be deviated from [...].

Moreover, $\S 3$ first subsection in the schedule provides further details on the spelling of Norwegian place-names:

The spelling of Norwegian place-names should follow the standard orthographical form or regional form which fits best with the inherited local pronunciation. Local dialectal forms can be adopted for special reasons. ${ }^{7}$

The Supplementary Rules for the Spelling of Norwegian Place-Names (Språkrådet 2018) provide further details on standard and regional forms permitted in the place-names.

Given the above, the extent to which local dialectal features are permitted by the laws is limited: local dialect, defined as the local inherited pronunciation, should be considered the fundamental basis for the spelling, but the spelling should still follow the standard form or regional form. Local dialectal forms are only permitted for special reasons. That said, regional forms, which represent local dialectal forms to some extent, are allowed. This can be seen as a compromise between dialect and standard.

\subsubsection{Dialect proximity principle}

There have been two main standpoints as to the question of how much weight dialects should be given in place-name standardisation (Helleland 1998: 147,161 ). One is that place-names should be spelled according to their (local) pronunciation "without consideration of the standard orthography or orthography rules", i.e. the dialect proximity principle (ibid.: 147). This view is particularly supported by local people and local authorities. This principle has historically never dominated within place-name standardisation. The other standpoint is that the spelling principles of the standard written languages are superior to pronunciations and only a limited degree of deviation from the standard orthography can be allowed. This view largely represents the placename standardisation of the 20th century, including the Place-Name Act. These two different approaches are also implemented to different degrees.

The main tendency within Norwegian place-name standardisation, as shown by the revisions carried out since the commencement of the Place-Name Act and other related regulations, has been the weakening of "the wish to establish a uniform toponomasticon" and "the view of place-names as a nationally shared

7 A regional form is "a written form which is not in accordance with official spelling, but often has a tradition in the standardisation of names, and is based on dialectal forms which are in use over wider areas". A local dialectal form is "a dialectal form without wide regional distribution or which is not usual to be expressed in such a way in the written form" (Språkrådet 2018). 
property" (Larsen 2018: 29). The weakening manifests itself partially in an increasing degree of allowance for dialectal forms in some specific writing rules.

Særheim (2008), one of a few recent studies touching upon the use of dialects in street names, is a good starting point to take to introduce the concrete practice of the dialect proximity principle and the related debates. The realisation of local dialectal features in Stavanger and Sandnes, two Western Norwegian municipalities, is manifest through the use of distinct vocabulary (-geilen 'narrow way') and grammar (different ending: dialect -gådå vs. standard -gata , def. sg. of gate 'street'). There are names whose spelling follows the dialect, but ignores the standard orthography, the Place-Name Act and related schedule, such as Kvednaberget $(r n>d n)$, Vodlaveien $(l l>d l)$ and Valbergiet $(g>g j)$ (ibid.: 79). Noticeably, the inconsistent standardisation of the same words is mentioned: Kvednabergjet vs. Kvernevik.

Two reasons for the dialect-close spelling of place-names have been discussed. First, it can serve to "preserve distinct local pronunciation in writing", which is supported by the idea of cultural preservation in the PlaceName Act (Særheim 2008: 80). This argument is also supported by the view that local pronunciation can only be passed down through active and continuous use (Søyland 2017: 43). A standardised, non-local form on maps and road signs can easily weaken local pronunciation. Particularly in places popular for tourism, local pronunciation of place-names can be influenced by immigrants and tourists. Second, the realisation of typical local dialectal features helps to make street names, which represent the local cultural history, unique and to express the roots and identity of the local residents (Særheim 2008: 80).

On the other hand, the pro-dialect approach is criticised for a lack of consideration of the practical function of place-names, namely as addresses: "place-names should first and foremost serve as geographical references, thus it is important that they have predictable and stable spellings" (Toten dialektog mållag, cited in Larsen 2018: 30). A further inclusion of local dialectal features in place-name standardisation has been argued to possibly lead to a risk of destabilising the public toponomasticon, increasing difficulties in "using it as a precise tool" for the public and "many inconsistencies both between municipalities and within each municipality" (Norwegian Mapping Authority, cited in Larsen 2018: 31).

\section{Hardanger and its dialect}

Hardanger is a traditional district in the south-east of Hordaland, a former Western Norwegian county. ${ }^{8}$ The district is located around the inner part of Hardangerfjorden with several other adjoining fjord districts. At the time I

8 Hordaland was merged into the new county of Vestland on 1 January 2020. 
carried out this study, there were seven municipalities in Hardanger. The district has an area of $6268 \mathrm{~km}^{2}$ (40.8\% of Hordaland) and 22,918 residents (4.4\% of the population in Hordaland, as of 2017, Thorsnæs 2017). Hardanger is famous for its stunning fjords. The sides of the fjords and the lower parts of some valleys are the main settlement areas. Industry, farming and tourist traffic play an important role in the economy there.

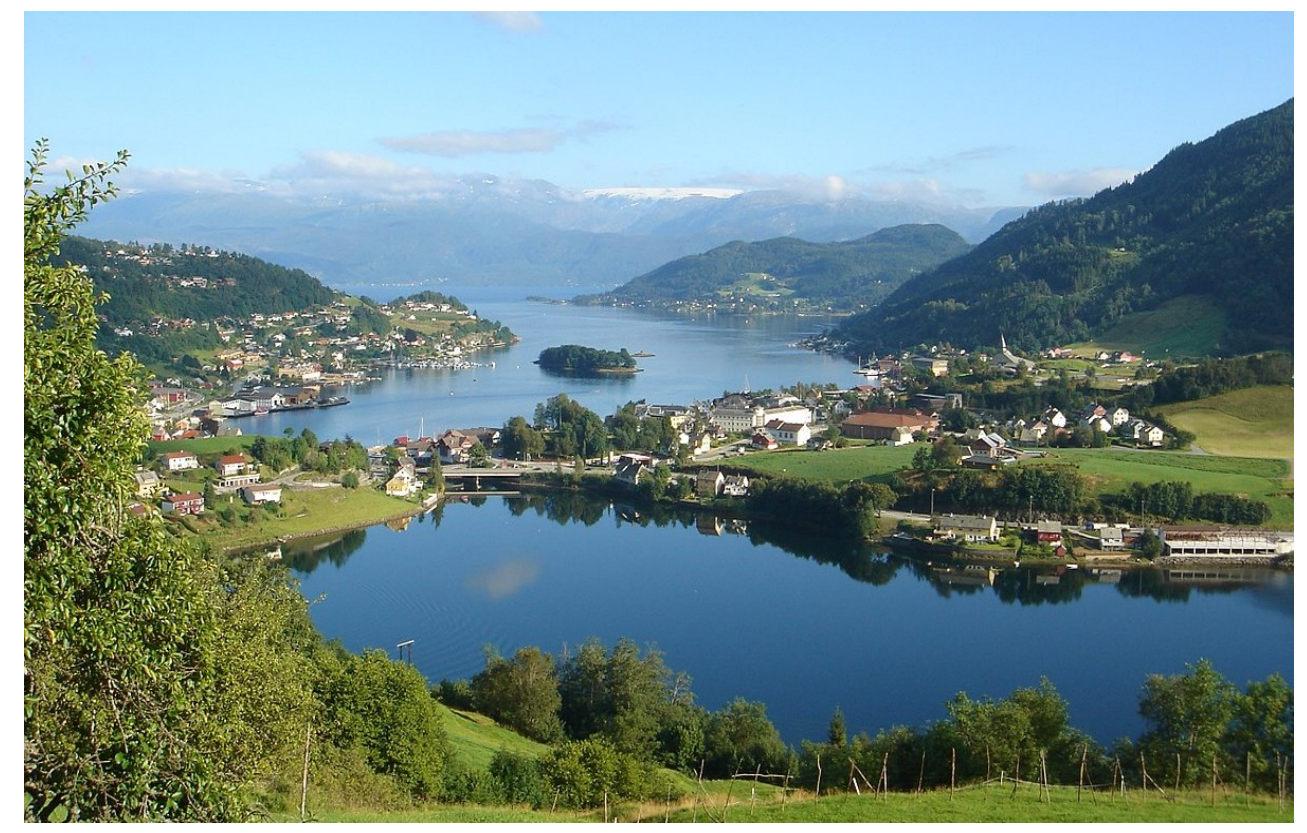

Figure 1: A view of part of the Hardanger Fjord from Norheimsund. Photo: Jan Aril Sivertsen, Wikimedia Commons.

The Hardanger dialect is a Western Norwegian dialect. The distance between the traditional Hardanger dialect and Nynorsk is supposed to be relatively small. Evidence for this is that Ivar Aasen, the founder of Nynorsk, considered the dialect of Hardanger among the best dialects to form the basis for Nynorsk of the time (Aasen 1997 [1853]: iv). Although there have been changes in Nynorsk and the Hardanger dialect since then, the distance between the two is still relatively minor regarding the language system (Helleland 2019). The use of the traditional Hardanger dialect has been in decline in recent years, evidenced by a piece of research on the dialect changes in Ullensvang by Lid (2015). 


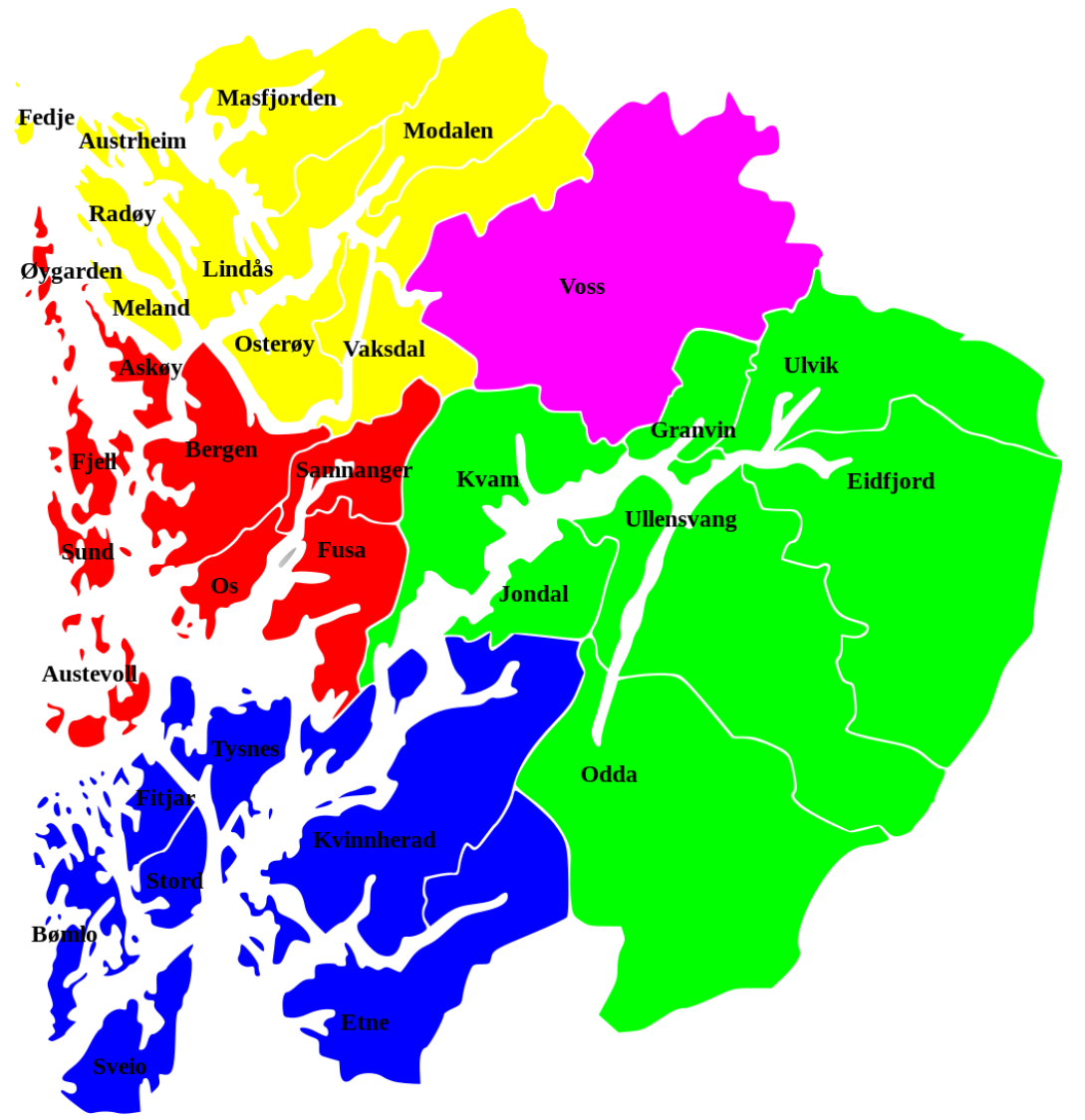

Figure 2: Map of municipalities and regions of Hordaland County before 2020. The part in green is Hardanger, where Granvin and Ullensvang are located. Picture: Wikimedia Commons.

Some of the characteristic features of the Hardanger dialect are (Helleland 2009): ${ }^{9}$

- $a o / a v /$ instead of $a / \mathrm{s} /$;

- $\varnothing y / ø i /$ instead of åy/oi/;

- $\dot{u}$, a distinct sound between $/ \mathrm{u} /$ and $/ \mathrm{u} /$;

- a strong tendency of palatalisation of $g / \mathrm{g} /$ and $\mathrm{k} / \mathrm{k} /: \mathrm{gj} / \mathrm{j} /$ and $\mathrm{kj} / \mathrm{ç} /$;

- different suffixed definite articles for strong and weak feminine nouns: $-\grave{e} / \varepsilon /$ (strong), $-o / \mathrm{u} /(\text { weak })^{10}$.

Most of these features will be examined in terms of their visibility in address names, together with a few other significant features. A detailed illustration of the selected features will be presented in 4.1.2. There is some variation in the Hardanger dialect(s) relating to location and age. For this work, only the variation of $\grave{u}$ in Ullensvang will be taken into consideration.

9 The phonetic transcriptions of all sounds here are based on Lid (2015: 46-48).

10 Generally, strong feminine nouns end with a consonant and their weak counterparts with a vowel. Moreover, Norwegian has a definite article in the form of suffix attached to noun. 


\section{Material and methods}

The research material, 145 address names from Granvin and Ullensvang, is drawn from a list of all address names in Norway, which is taken by the Norwegian Mapping Authority from the land register (Trones 2018). The list of address names I obtained was updated on 11 February 2019.

\subsection{Method for research question 1}

\subsubsection{General}

The extent to which local dialectal features are realised in address names will be calculated through dividing the actual realisation of local dialectal features by the sum of the potential and actual realisations of local dialectal features. This requires the identification of both the potential and existing local dialectal features in address names. A potential dialectal feature is a feature that is not realised but could have been realised. An existing dialectal feature is a feature that is realised. Only a selection of local dialectal features will be examined.

To identify the relevant potential and existing local dialectal features, two methods will be used together:

1) Assumption: I have judged which name has potential or existing dialectal feature(s), using my knowledge of the Hardanger dialect. From summer 2018 to spring 2019, I studied it with the help of Botolv Helleland and Erlend Trones and some related literature. ${ }^{11}$ I have had lots of written communication in the dialect.

2) Database evidence: I have verified my assumptions by checking the local pronunciation of names in the place-name database Hordanamn. Since the dialect is not my mother tongue, Hordanamn will help to increase the accuracy of my assumptions.

As examples of names with potential or existing local dialectal features, we may look at the names Vetlås and Kvednavegen. Expectedly, in Vetlås /vetlo:s/, -ås "hill" should be pronounced /av:s/ and written as Vetlaos in the dialect $(/ \mathrm{s} />/ \mathrm{a} / /)$. Database evidence shows the name Vetlais is not featured, but many names with -ås are featured, all pronounced /av:s/. Therefore, Vetlås is a name with one potential dialectal feature. In Kvednavegen /kvednave:jen/, $k v e d n$ - is a dialectal form of kvern 'mill' $(r n>d n)$. Additionally, instead of -e-, $-a$ - is used, which is dialectal, but not standard in Nynorsk: Kvernevegen. Database evidence shows that Kvednavegjen is found four times. ${ }^{12}$ Therefore, Kvednavegen is a name with two existing dialectal features.

11 Helleland and Trones are dialect and place-name researchers. See the Acknowledgement.

12 The generic term -vegen 'the street' will be excluded from examination. It is a potential dialectal feature, as it should be pronounced as vegjen /ve:jen/ in the dialect. However, it is so frequent that counting it every single time where possible would result in a deceptively high number of the potential dialectal features. 
As shown above, there is not always an exact form of the names in question in the database. In this case, evidence for features to be examined from other items can be used, as shown with Vetlås. This alternative method is based on two assumptions: the features in question should be realised consistently, and local dialectal features are often better preserved in placenames than in common nouns. This might be a bit too idealised but is sufficient for this project and can be improved in future.

Once all names have been analysed in terms of having the relevant existing or potential dialectal features, they are arranged into three groups:

1) names with existing dialectal feature(s), marked by $E$;

2) names with potential dialectal feature(s), marked by P;

3) names without existing or potential dialectal features, marked by $\varnothing$.

Finally, the number of names in group 1 is divided by the sum of the numbers of names in groups 1 and 2, in order to work out the extent of the (actual) realisation of local dialectal features.

\subsubsection{Traditional local dialectal features to be examined}

11 features from the Hardanger dialect were chosen to be examined. It is worth noting that not all features below will apply in Granvin and Ullensvang, for two reasons. First, a few features are applicable in names from Granvin but not from Ullensvang, or vice versa. For instance, although $-o$ as the suffixed definite article for weak feminine nouns is used in Ullensvang, no address names from there have this grammatical category. Second, there are a few features that only Ullensvang has retained, such as $\dot{u}$. The features that apply for each place will be presented in 5.1.

Table 1: Phonological features to be examined.

$\mathrm{HD}=$ Hardanger dialect, $\mathrm{NN}=$ Nynorsk, $\mathrm{EN}=$ English .

\begin{tabular}{|c|c|c|c|c|c|}
\hline & \multicolumn{2}{|c|}{ Feature } & \multicolumn{3}{|c|}{ Example } \\
\hline & HD $^{\text {a) }}$ & $\mathbf{N N}^{\mathrm{b})}$ & HD & $\mathbf{N N}$ & EN \\
\hline 1 & $<\mathrm{ao}>/ \mathrm{a} \sigma /$ & $<\stackrel{a}{>}>$ & baot & $b \underline{a} t$ & boat \\
\hline 2 & $<$ oy $>$ /oi/ & $<\varnothing y>$ & $\underline{\underline{o y}}$ & $\underline{\underline{y y}}$ & island \\
\hline 3 & $<\mathrm{dl}>/ \mathrm{dl} /$ & $<\mathrm{ll}>$ & fjedl & fjell & mountain \\
\hline 4 & $<\mathrm{dn}>/ \mathrm{dn} /$ & $<\mathrm{rn}>$ & $b a \underline{d n}$ & barn & child \\
\hline 5 & $<\mathrm{gj}>/ \mathrm{j} /$ & $<\mathrm{g}>$ & hagjen & hagen & the garden \\
\hline 6 & $<\mathrm{kj}>/ \mathrm{ç} /$ & $<\mathrm{k}>$ & bakkjen & bakken & the hill \\
\hline
\end{tabular}

a) The dialect-close spelling is used here.

b) Since Nynorsk is a written language, no pronunciation is suggested. 
Table 2: Morphological features to be examined.

$\mathrm{HD}=$ Hardanger dialect, $\mathrm{NN}=$ Nynorsk, $\mathrm{EN}=$ English .

\begin{tabular}{|c|c|c|c|c|c|c|}
\hline & \multicolumn{3}{|c|}{ Feature } & \multicolumn{3}{|c|}{ Example } \\
\hline & Category & HD & $\mathbf{N N}$ & HD & NN & EN \\
\hline 7 & $\begin{array}{l}\text { Def. article for weak } \\
\text { feminine nouns in sg. }\end{array}$ & $\begin{array}{l}-o \\
/ \mathrm{u} /\end{array}$ & $-a$ & skoddo & skodda & the fog \\
\hline 8 & $\begin{array}{l}\text { Def. article for strong } \\
\text { feminine nouns in pl. }\end{array}$ & $\begin{array}{l}-\grave{e} \\
\mid \varepsilon /\end{array}$ & $-a$ & myrè & myra & the bog \\
\hline 9 & $\begin{array}{l}\text { Def. article for } \\
\text { masculine and } \\
\text { feminine nouns in pl. }\end{array}$ & $\begin{array}{l}\text {-ena } \\
\text { /ena/ } \\
\text { /-ùna }{ }^{\mathrm{c}}\end{array}$ & -ene & bruena & bruene & $\begin{array}{l}\text { the } \\
\text { bridges }\end{array}$ \\
\hline 10 & joining morpheme $1^{\mathrm{d})}$ & $\begin{array}{l}-a- \\
/ \mathrm{a} / \mathrm{e})\end{array}$ & $-e-$ & Vatnasete & Vatnesete & $\begin{array}{c}\text { lake } \\
\text { pasture }\end{array}$ \\
\hline 11 & joining morpheme $2^{\mathrm{f}}$ ) & $-\grave{u}-$ & $-e-$ & Kyrkjüudoé & Kyrkjędoet & $\begin{array}{c}\text { the church } \\
\text { toilet }\end{array}$ \\
\hline
\end{tabular}

c) -ùna applies in Ullensvang only.

d) In Norwegian, a morpheme is often needed to join two elements together to coin a compound.

e) Unlike with the other features, I will simply record the frequency of $-a$ - found in the address names (existing), not exploring where it could have appeared (potential). Which joining morpheme is traditionally used depends on some grammatical categories of the first element of a compound. Due to time constraints, I cannot examine this in detail. However, $-a$ - is highly visible in the address names in both places, probably due to the place-name regulations (see 5.2), so it can be expected that the extent of the realisation of - $a$ - is very high. This means that there might be only a few cases where $-a$ - is a potential feature, which would marginally contribute to the number of potential dialectal features and thus only make minor changes to the overall result.

f) This applies to some parts of Ullensvang. - $\grave{u}$ - as a joining morpheme will still be examined in terms of potential realisation, as it is much easier to predict than $-a-$.

There are reasons for this particular selection. First, these features are non-standard in Nynorsk, except, to a limited degree, the realisation of the palatalisation of $/ \mathrm{k} /$ and $/ \mathrm{g} /$ and the use of $-a$ - as joining morpheme in a few words. Second, most of them are typical of the traditional Hardanger dialect, thus representing its distinctiveness. This does not mean that they are unique: features 3-8 and 10 have a wider distribution, while features 1,2 and 11 are more characteristic for (Inner) Hardanger. ${ }^{13}$ This will be interesting from a comparative perspective: as shown in 2.2.3., there is enthusiasm for and implementation of those widely shared features, such as $r n>d n, l l>d l$ and $g>g j$. It will be interesting to see whether these are realised in the two municipalities too. Equally crucial are the more characteristic features: have they been realised, in order to preserve local pronunciation as part of culture and express the identity of the locals?

Not least, what I suppose can represent the traditional dialect, namely these features, might not necessarily be the same as what the locals perceive as

13 Regarding feature 9, -ena has a slightly wider distribution, whereas the use of -ùna is more limited (Helleland 2019). 
representative of their dialect. This can be explained by differences in the ways to approach language between linguists and non-linguists: the former tend to analyse the language and start with segments, whereas the latter tend to depend on feelings and obtain a whole picture of the language. This work will take the linguist's approach.

\subsubsection{Hordanamn}

Hordanamn is a database for place-names in Hordaland. It provides among other things recordings of the local pronunciation of names and their phonemic transcriptions, which help to test my assumptions about whether the address names in question have existing or potential local dialectal features. Not all municipalities in Hordaland are included in Hordanamn. For Hardanger, only three of the seven former municipalities are included, i.e. Gravin and Ullensvang.

The place-names from Granvin and Ullensvang were collected at slightly different times (K. E. Steinbru, personal communication, 21 \& 22 February 2019). Names from Granvin were collected between 1989 and 1994. Some names in Ullensvang were collected between 1969 and 1976, and the rest were collected between 1980 and 2015. People who collected place-names were local and trained by professionals. Regarding the criteria for the selection of informants, the name collectors were strongly encouraged to consult those who were born and grew up locally and who were more than 50 years old. Many of the informants were farmers.

Judging from my knowledge of the Hardanger dialect, the recorded pronunciations and their phonemic transcriptions of the place-names from Granvin and Ullensvang generally show typical features of the traditional Hardanger dialect, therefore Hordanamn is a reliable source for my research.

There are a few problems with the recording and transcriptions. The phonemic transcription is unfortunately inconsistent, although the problems generated by this are minor. Moreover, the pronunciation of place-names in Ullensvang is not recorded. Also, the quality of the recordings for place-names in Granvin is not always clear, occasionally causing problems for the identification of the sounds in question.

In cases where the problems above caused difficulties in finding or identifying pronunciations in Hordanamn, I have consulted Botolv Helleland (2019) and Erlend Trones (2018). In cases where there are no entries containing the names or name elements in question, other sources are employed, such as Norwegian farm names (e.g. Olsen \& Rygh 1910) and Norwegian place-name encyclopedia (Sandnes \& Stemshaug 1997). 


\subsection{Method for research question 2}

To answer this question, the realised local dialectal features will be examined in terms of whether they deviate from the aforementioned placename regulations: the Place-Name Act, the Schedule of the Place-Name Act, and the Supplementary Rules for the Spelling of Norwegian Place-Names in their current versions. Thus, the question will be answered from a synchronic perspective. ${ }^{14}$ It is worth noting that I will use the main rules to carry out the examination. As mentioned, local dialectal forms may be used for special reasons, implying some degree of latitude. This will not be the focus here. In cases where the regulations do not directly address the features in question, I have consulted Botolv Helleland and Erlend Trones.

\section{Results}

\subsection{To what extent are the traditional local dialectal features visible in address names in Granvin and Ullensvang?}

Table 3: Numbers of address names of different categories in Granvin and Ullensvang

\begin{tabular}{|r|c|c|c|c|}
\hline & \multicolumn{2}{|c|}{ Granvin } & \multicolumn{2}{c|}{ Ullensvang } \\
\hline & Number & $\mathbf{\%}$ & Number & $\mathbf{\%}$ \\
\hline $\mathbf{P}$ & 15 & $19.2 \%$ & 24 & $35.8 \%$ \\
\hline $\mathbf{E}^{\mathbf{g})}$ & $11+5^{*}$ & $20.5 \%$ & $4+6^{*}$ & $14.9 \%$ \\
\hline $\boldsymbol{\varnothing}$ & 46 & $59.0 \%$ & 32 & $47.8 \%$ \\
\hline $\mathbf{?}^{\mathbf{h})}$ & 1 & $1.3 \%$ & 1 & $1.5 \%$ \\
\hline Total & $\mathbf{7 8}$ & $\mathbf{1 0 0 \%}$ & $\mathbf{6 7}$ & $\mathbf{1 0 0 \%}$ \\
\hline
\end{tabular}

g) Some names have more than one feature in question. They are considered as names with existing dialectal features, (even) if (only) one of the features is realised. These names will be discussed separately. The number of this type of names is marked by an asterisk.

h) This denotes names that cannot be categorised into the groups above due to doubts.

Table 3 shows that 31 out of 78 names in Granvin and 34 out of 67 names in Ullensvang have either existing or potential dialectal features, making up $39.7 \%$ and $50.7 \%$ of the whole in the respective places. The dialectal features were realised in 16 of 31 relevant names (51.6\%) in Granvin and in 10 of 34 names $(29.4 \%)$ in Ullensvang. These figures give an impression that the extent to which the non-standard local dialectal features in these two municipalities are realised is not low, or even high. However, this impression will change if we scrutinise what features are (un)realised.

14 The current versions refer to the versions in March 2019. 
Table 4: Frequency of realisation of individual features in address names in Granvin and Ullensvang

\begin{tabular}{|c|c|c|c|}
\hline Group & Feature & $\begin{array}{c}\text { Frequence of } \\
\text { realisation } \\
\text { (Granvin) }\end{array}$ & $\begin{array}{l}\text { Frequence of } \\
\text { realisation } \\
\text { (Ullensvang) }\end{array}$ \\
\hline \multirow[t]{6}{*}{$\mathbf{A}$} & $\stackrel{\circ}{a}>a o$ & $0 / 5$ & $0 / 5$ \\
\hline & $\varnothing y>a ̊ n y$ & $0 / 3$ & $0 / 3$ \\
\hline & $k>k j$ & $1 / 3$ & $1 / 4$ \\
\hline & $g>g j$ & $0 / 2$ & $0 / 2$ \\
\hline & $-\grave{u}$ - as joining morpheme & - & $0 / 5$ \\
\hline & $\begin{array}{l}\text { Def. article for mas. and fem. } \\
\text { nouns in pl. -ene>-èna/-ùna }\end{array}$ & - & $0 / 5$ \\
\hline \multirow[t]{4}{*}{ B } & $l l>d l$ & $1 / 4$ & $0 / 3$ \\
\hline & $r n>d n$ & $0 / 2$ & $3 / 5$ \\
\hline & $\begin{array}{l}\text { Def. article for weak feminine } \\
\text { nouns in sg. }-a>-o\end{array}$ & $1 / 1$ & - \\
\hline & $\begin{array}{l}\text { Def. article for strong feminine } \\
\text { nouns in sg. }-a>-\grave{e}\end{array}$ & - & $0 / 1$ \\
\hline \multirow[t]{2}{*}{$\mathbf{C}$} & $-a-$ as joining morpheme $\mathrm{e}^{\mathrm{i})}$ & $15 / 15$ & $9 / 9$ \\
\hline & Total & $18 / 35$ & $13 / 42$ \\
\hline
\end{tabular}

i) See note e) under Table 2 .

As shown in Table 4, $-a$ - as a joining morpheme, which is also the most widespread among the features chosen, is frequently realised, making up $15 / 18=83.3 \%$ of the realisation of the local dialectal features in Granvin and $9 / 13=69.2 \%$ in Ullensvang. In both municipalities, more dialect-specific features (group A) are hardly realised. More widespread features (group B) are marginally realised, apart from $r n>d n$ in Ullensvang. This exception is remarkable and interesting, as 3 out of the 5 cases are realised, unlike the other features in groups A and B. Now, let us scrutinise those names containing more than one feature in question.

Table 5: Address names with more than one existing dialectal feature in Granvin and Ullensvang

\begin{tabular}{|l|l|c|c|}
\hline & Name & Realised feature & Unrealised feature \\
\hline \multirow{4}{*}{} & Hagabrekko & $-a-,-a>-o$ & \\
\cline { 2 - 4 } & Håstabbastølen & $-a-$ & $a>a o$ \\
\cline { 2 - 4 } & Nodlavegen & $-a-, l l>d l$ & \\
\cline { 2 - 4 } & Vallavikvegen & $-a-$ & $l l>d l$ \\
\cline { 2 - 4 } & Asingavegen & $-a-$ & $a>a o$ \\
\hline \multirow{3}{*}{} & Djønnaneset & $-a-$ & $r n>d n$ \\
\cline { 2 - 4 } & Flisabakken & $-a-$ & $-a>-\grave{e}$ \\
\cline { 2 - 4 } & Hausalia & $-a-$ & \\
\cline { 2 - 4 } & Kvednavegen & $-a-, r n>d n$ & \\
\cline { 2 - 4 } & Modnavegen & $-a, r n>d n$ & \\
\cline { 2 - 4 } & Tjødnahaugane & $-a, r n>d n$ & \\
\hline
\end{tabular}


The realisation of this type of names is reflected by what is shown in Table 4 to some extent, i.e. the high degree of visibility of $-a$ - in both municipalities as opposed to most of the other features, except $d n$ in Ullensvang. In 3 of these 5 cases in Granvin, it is only due to the realisation of $-a$ - that the names concerned are considered as names with existing features. The features other than $-a$ - are barely visible. Compared to this, 3 of those 6 names in Ullensvang could have still been considered as names with existing dialectal features, even if they did not have - $a$-. This is due to the realisation of $d n$.

Overall, the relatively high percentage of names with existing dialectal features in address names from Granvin $(51.6 \%)$ and Ullensvang $(29.4 \%)$ is mainly ascribed to the realisation of $-a-$. The realisation of the other features is quite low in both places, with $d n$ in Ullensvang as an exception. In other words, the extent to which the non-standard local dialectal features are realised in the address names in Granvin and Ullensvang is actually relatively very low. The realisation of $-a$ - gives a deceptive impression of a much higher degree of visibility of the local dialectal features.

\subsection{To what extent does the realisation of the traditional local dialectal features deviate from the place-name regulations?}

Section 5.1. has shown that the extent to which the non-standard local dialectal features are realised in the address names in Granvin and Ullensvang is very low, i.e. a very Nynorsk-close presentation. Given this, it is particularly interesting to scrutinise those names that have not been Nynorsk-standardised but retained their dialectal features. I will examine whether there are legal grounds for the realisation of those features non-standard in Nynorsk, using the aforementioned three regulations.

\subsubsection{Granvin}

Velkjesvegen: Velkje- refers to the farm name Velkje, a dialectal form of Velken, whose historical form is Valkvin (Olsen \& Rygh 1910: 486). As Velkje is not generally recognisable, its spelling should follow the standard orthographical rules rather than the standard orthography according to paragraph 1 first subsection in the Schedule of the Place-Names Act (Trones 2018). $\mathrm{kj} / \mathrm{c} /$ is the result of the palatalisation of $k / \mathrm{k} /$ triggered by the following high vowel $e / \varepsilon /$ : Velken $>$ Velkjen. According to the standard orthographical rules, /ç/ in word-final positions is normally standardised as $k$, not $k j . k j$ is usually employed if the historical form of a word has $k j$ (Helleland 2019). The historical form Valkvin does not have $k j$. Overall, there are no grounds for $k$ to be written as $k j$ according to the standard orthographical rules, i.e. it is a deviation. Additionally, there is no rule specifically addressing the spelling $k>k j$, implying that $k j$ is not encouraged.

Nodlavegen: Nodla- refers to Nollen, which is generally unrecognisable 
(Trones 2018). Therefore, the standard orthographical rules should be followed in this case. $/ 11 /$ is generally normalised as $l l$, so the use of $d l$ breaches paragraph 1 first subsection in the schedule. Similarly, there is no rule specifically addressing the spelling $l l>d l$, implying that $d l$ is not encouraged.

Hagabrekko: $-o$ is permitted. Section 4.2.2. in the Supplementary Rules for Spelling of Norwegian Place-Names states that $-o$ can be used as definite suffixed article for weak feminine nouns in accordance with the dialect (Språkrådet 2018).

Names with - $a$ - as joining morpheme: $-a$ - is permitted. Section 6 in the supplementary rules advises to follow the dialect regarding the way of coining compounds (Språkrådet 2018).

\subsubsection{Ullensvang}

Krikkjenvegen: Krikkjen is a dialect variant of krikk 'natural feature shaped as a corner', which is in turn a variant of krik (cf. Ross \& Aasen 1895: 429). Interestingly, krikkjen is accepted as a terrain-describing word and the acceptance accords to the standardisation tradition for such dialectal or regional words (Helleland 2019). However, Krikkjen- does not follow the traditional way to coin compounds in the dialect: the suffixed definite article -en should be removed and $-a$ - should be attached, in accordance with section 6 in the supplementary rules. Thus, it is a deviation.

Kvednavegen, Modnavegen, Tjødnahaugane: Kvedna-, Modna- and Tjødna- refer to kvern 'mill', moen 'the moor', and tjørn 'small forest lake'. They are generally recognisable and should thus follow the standard orthography. Given this, the use of $d n$ breaches paragraph 1 first subsection in the schedule. Moreover, according to section 3.6. in the supplementary rules, for $r n$ to be spelled as $d n$, there should be special reasons. This means that $d n$ is strictly speaking not allowed.

Names with $-\boldsymbol{a}$ - as joining morpheme: As mentioned, this is recommended.

Overall, except $-o$ in Hagabrekko and - $a$-, the use of the other local dialectal features in the names in Granvin and Ullensvang breaches the main rules of the place-name regulations.

\section{Discussion}

The two research questions, presented in the introduction, can be shortly answered as follows:

1) The extent to which the traditional local dialectal features are realised in the address names is very low in both Granvin and Ullensvang.

2) Except the joining morpheme - $a$-, of which there are many cases, most of the other local dialectal features shown in a few names are not allowed according to the main rules of the place-name regulations. These findings lead to further queries. First, why is the visibility of the 
traditional dialect relatively very low in Granvin and Ullensvang? Second, considering the standard-close impression of the address names, are there any special reasons for the unpermitted use of those local dialectal features?

As we have already seen, the place-name regulations principally do not permit local dialectal features, unless there are special reasons. This is, however, presumably only one possible reason why the address names in these two municipalities are very standard-close. As mentioned earlier, there are many cases where local communities do not comply with the Place-Name Act for various reasons. This means that the implementation of the regulations plays a crucial role in the standardisation and should be examined.

The implementation process involves several parties: administration in local municipalities and local residents, the Norwegian Mapping Authority and the Place-Name Standardisation Service in the Language Council of Norway. As addressed before, there tends to be a split between the state and the local level: pro-standard versus pro-dialect. The Norwegian Mapping Authority has paid particular attention to the address names in Ullensvang, so that they comply with the act (Trones 2018). It will be interesting to investigate the local administrations and people in Granvin and Ullensvang. The following questions can be asked: why is the degree of dialect visibility in the address names generally low? Are the administrations pro-standard themselves or pressured to be so by the Norwegian Mapping Authority? Moreover, why do the local administrations and people not promote the local dialectal features, particularly considering that Hardanger is a place popular for tourism? Why do they not preserve the local dialect in place-names as part of the local culture and expression of the local identity? Not least, why have some address names retained dialectal features?

Unfortunately, these questions cannot be answered directly at the time I carried out this study, due to multiple unsuccessful attempts to reach the municipal administrations in Granvin and Ullensvang and time limitations preventing the full ethical approval process required for interviewing the local residents.

However, there are some clues for those questions. The local people and administrations might perceive that Nynorsk represents the Hardanger dialect well enough, due to the relatively small distance between them. Thus, there might not be a strong wish from the local level to make their dialect in the address names (even) more visible.

Moreover, according to Helleland (2019), place-name standardisation in Granvin and Ullensvang has been based on the standard orthography and orthographical rules, but the administrations appear to be pro-dialect occasionally. A frequently used dialectal form is more likely to be preserved in writing. Locals in strong positions can sometimes also contribute to making dialectal forms realised. On the other hand, the municipal administrations often do not have competence in implementing forms that comply with the regulations. They did not always consult the Place-Name Standardisation Service, which they should have done according to the regulations. When they 
have done so, they have not always followed the advice given.

This echoes the standard-close picture with a few dialectal ornaments shown in the address names from Granvin and Ullensvang. Moreover, the information above provides further clues on how to investigate reasons for the unpermitted use of the local dialectal features in those few names: are there local people in strong positions involved? Have the dialectal forms been established for a long time? Or do the municipal administrations ignore the advice from the professional bodies?

Krikkjenvegen discussed earlier can address these questions to some extent. From a previous version of the address list updated on 27 August 2018, I questioned the unusual use of -en- with Erlend Trones. He replied on 23 September 2018 that -en- does not follow the traditional system in the dialect and phoned the local administration to request a change, preferably to Krikkavegen with - $a$-. This change has, as shown in the version of the address list updated on 11 February 2019, not been made (after nearly 5 months). This might be an example of what Helleland (2002: 70) says, namely the lack of knowledge about coining forms that comply with the regulations and the unwillingness to follow the standardisation rules.

Having a look at the location of those streets with names deviating from the regulations can also give some hints. The three streets named Kvednavegen, Modnavegen and Tjødnahaugane are found close to each other in a residential area in Kinsarvik, Ullensvang. It is possible that residents on these streets have played a role in the implementation of $r n>d n$. And if $r n$ is spelled as $d n$ in one name, it seems to be natural to spell it as $d n$ in a neighbouring name too. However, this is not a primary reason for the spelling of $d n$, which means that consultation with the local administration and people is necessary for more details.

\subsection{Does the high degree of dialect diversity and tolerance also apply to Norwegian place-names?}

On the surface level, it seems that the degree of dialect diversity and tolerance is not as high as one might expect, as the majority of the local dialectal features in question are not visible. However, 145 names are an extremely small part of the entire Norwegian toponomasticon and even of the toponomasticon in the two municipalities. Therefore, no conclusion can be drawn for place-name standardisation across the entire country. Additionally, only some of the local dialectal features were chosen to be examined. What can be said from this is only that most of these selected features are hardly visible in the address names examined.

On the other hand, there are names with local dialectal features that are not standard in Nynorsk but recommended in the place-name regulations, such as $-o$ as in Hagabrekko and $-a$ - as a joining morpheme. Although the number of the features recommended is very low, it is a good piece of evidence that 
dialect diversity and tolerance apply to Norwegian place-names too and even to a larger degree compared to appellatives. Moreover, Nynorsk is used as one of the two linguistic guidelines for the place-name standardisation. If Bokmål, which is linguistically relatively remote from the Hardanger dialect, were the only guideline, the Hardanger dialect would be presented to a lesser extent. The use of Nynorsk or the freedom when choosing the written standard has contributed to dialect visibility in place-names already. Based on the above, it can be said that Norwegian place-name standardisation allows dialect diversity, although the exact extent of this requires further investigation studying a wider range of dialectal features, other names and other parts of Norway.

\subsection{Why does place-names standardisation (seem to) show an even higher degree of dialect diversity and tolerance?}

As proper nouns, place-names do not need any morphological ornaments (Hallaråker 1997: 194). They serve as geographical references. Whether it is spelled as Hagebrekka or Hagabrekko, the name will refer to the same object. However, place-names often overlap with appellatives (ibid.: 199). For instance, -brekke in Hagabrekko can also be found in the lexicon, and there is a definite form: brekka (standard) or brekko (dialect). ${ }^{15}$ Dealing with these subtle linguistic details brings us to the cultural function of place-names. As discussed before, keeping dialectal features in place-names contributes to the preservation of local culture. The use of a dialectal feature typical of one particular place/region can contribute to distinguishing one name and related place from others, thereby helping to express, emphasise and construct the uniqueness of the name and related place to a larger degree, i.e. identity.

\subsection{Future outlook}

I have already discussed some limits or future possibilities of this project, such as possible fieldwork investigating the local administrations' and residents' role in the standardisation of the address names, as well as a larger project examining a wider range of data. It would also be interesting to examine the visibility of features that the locals perceive as characteristic of their dialect and whether place-name standardisation in Norway also has a higher degree of dialect diversity than that in other countries.

\section{Conclusion}

In this work, I have shed light on the question of to what extent dialect diversity and tolerance apply to place-names in Norway, based on a survey of 145 address names in Granvin and Ullensvang, two former municipalities in

15 Brekke is the default dictionary form (singular and indefinite). 
Hardanger, Western Norway. 11 selected traditional local dialectal features, which are non-standard in Nynorsk but might be allowed by the place-name regulations, have been examined in terms of their visibility in the address names. The findings show that most of these features are not visible. This suggests that the address names in both places are very standard-close. To have a better understanding of the implementation of place-name standardisation in these two municipalities, an investigation studying the local administrations and residents would be necessary.

On the other hand, there are a few features that have been realised in the names, and a few of them are allowed by the main rules of the current placename regulations. This is a piece of evidence that dialect diversity and tolerance apply to Norwegian place-names, at least to some extent. To obtain a fuller picture of dialect diversity and tolerance in Norwegian place-names, more dialectal features, more place-names and other parts of Norway need to be examined.

\section{Acknowledgement}

This article is a reworked version of my undergraduate dissertation, submitted to the University of Edinburgh in March 2019 as part of my undergraduate studies in Scandinavian Studies and Linguistics. I would like to thank Dr Arne Kruse and Dr Guy Puzey (University of Edinburgh) for their supervision, ass. Prof. emerit. Botolv Helleland (University of Oslo and Language Council of Norway) and Erlend Trones (Norwegian Mapping Authority) for helping me to learn the dialect and place-names of Hardanger, and Kjell Erik Steinbru (Language Council of Norway) for his help with the research material. For non-academic support, I would particularly like to thank Di Chen, Knut Espen Arnesen, Luciena Xiao, Odd Gunnar Tveit, Per Østvold, Shiqi Dai, Tianheng Yang, Wolfram Hoppe, Yat Nam Chung, Yuwei Chen, and not least my mother Feifei Liu.

\section{References}

Aasen, Ivar. 1997 [1853]. [Preface] in Prøver af Landsmaalet $i$ Norge [Samples of Landsmaal in Norway], I-IV. (https://www.aasentunet.no/wpcontent/uploads/2019/01/Pr\%C3\%B8ver-af-Landsmaalet.pdf) (Accessed 2020-02-28.)

Forskrift om eiendomsregistrering [Schedule of the Land Register]. 2009. (https://lovdata.no/dokument/SF/forskrift/2009-06-26-864) (Accessed 201903-26.)

Forskrift om stadnamn [Schedule of the Place-Name Act]. 2017. (https://lovdata.no/dokument/SF/forskrift/2017-05-23-638?q=forskrift\% 20om\%20stadnamn) (Accessed 2019-01-12.) 
Hallaråker, Peter. 1997. Innføring i stadnamn: Innsamling og gransking [Introduction to place-names: Collection and research]. Oslo: Universitetsforlaget.

Helleland, Botolv. 1998. Dialektsynet i norsk stadnamnnormering [On the use of dialects in Norwegian place-name standardisation]. In Akselberg, Gunnstein \& Bondevik, Jarle (eds.), Ord etter ord. Heidersskrift til Oddvar Nes 27. desember 1998 [Word by word. Festskrift for Oddvar Nes 27 December 1998], 147-162. Bergen: Norsk bokreidingslag.

Helleland, Botolv. 2002. Stadnamnrøkt og stadnamnnormering i dei nordiske landa [Place-name preservation and place-name standardisation in the Nordic countries]. In Sprauten, Knut (ed.), A kallast med sitt rette namn: person- og stadnamn i lokalhistoria [To be called by the right name: Personal names and place-names in the local history], 43-74. Oslo: Norsk lokalhistorisk institutt.

Helleland, Botolv. 2009. Hardanger - Språk [Hardanger-Language]. Store norske leksikon [Great Norwegian encyclopedia]. (https://snl.no/Hardanger_spr\%C3\%A5k) (Accessed 2019-02-05.)

Helleland, Botolv. 2019. Personal communication (18-25 March 2019).

Landsmål. 2018. Store norske leksikon [Great Norwegian encyclopedia]. (https://snl.no/landsm\%C3\%A51) (Accessed 2019-03-26.)

Larsen, Terje. 2018. Nye reglar for skrivemåten av norske stadnamn [New rules on the spelling of Norwegian place-names]. Nytt om namn 2017 $(65 / 66), 29-31$.

Lid, Hallvard. 2015. "Men Odda e' jo da naturle' sentere' fý oss, dao" Ei sosiolingvistisk gransking av variasjon og endring $i$ dialekta $i$ Ullensvang herad ["But Odda is of course the natural centre for us". A sociolinguistic study on variation and change in the dialect of the municipality of Ullensvang]. University of Bergen. (Master's dissertation.)

Lov om stadnamn [Place-Name Act]. 1990 (amended in 2015 and 2019). (https:// lovdata.no/dokument/NL/lov/1990-05-18-11) (Accessed 2019-01-12.) ${ }^{16}$

Olsen, Magnus \& Rygh, Oluf. 1910. Gaardnavne i Søndre Bergenshus Amt. Bd. 11, Norske Gaardnavne. Oplysninger samlede til Brug ved Matrikelens Revision [Farm names in Southern Bergenshus Amt. Volume 11, Norwegian farm names. Information collected for use in the revision of the Land Register]. Kristiania: W.C. Fabritius \& Sønner A/S.

Ross, Hans \& Aasen, Ivar. 1895. Norsk ordbog: Tilloeg til "Norsk ordbog" af Ivar Aasen [Norwegian dictionary: Addendum to "Norwegian Dictionary" by Ivar Aasen]. Christiania: Cammermeyer.

Røyneland, Unn. 2009. Dialects in Norway: Catching up with the rest of Europe? International Journal of the Sociology of Language 196-197, 7-30. DOI: https://doi.org/10.1515/IJSL.2009.015

16 The act was amended again on 1 July 2019, after this study. 
Sandnes, Jørn \& Stemshaug, Ola. 1997. Norsk stadnamnleksikon [Norwegian place-name encyclopedia], 4th edition. Oslo: Det Norske Samlaget.

Språkrådet [Language Council of Norway]. 2018. Utfyllande reglar om skrivemåten av norske stadnamn [Supplementary Rules for the Spelling of Norwegian Place-Names]. (https://www.sprakradet.no/Sprakarbeid/ Stedsnavn/utfyllande-reglar-om-skrivematen-av-norske-stadnamn/) (Accessed 2019-01-12.)

Særheim, Inge. 2008. Urbane namn og kulturell identitet. Offisiell namngjeving i ein europeisk kulturhovudstad [Urban names and cultural identity. Official naming in a European cultural capital]. Namn og nemne 2007(24), 65-81.

Søyland, Aud. 2017. Kvifor målføreformer i vegnamn? [Why dialectal forms in street names?]. Nytt om namn 2016 (63/64), 40-44.

Thorsnæs, Geir. 2017. Hardanger. Store norske leksikon [Great Norwegian encyclopedia]. (https://snl.no/Hardanger) (Accessed 2019-01-29.)

Trones, Erlend. 2018. Personal communication (from 21 September 2018 to 9 February 2019).

UNGEGN. 2006. [Introduction] Manual for the national standardization of geographical names, 1-4. New York: United Nations. 